\title{
Micronutrient Status and Selected Physiological Parameters of Roots in Nickel-Exposed Sinapis alba L. Affected by Different Sulphur Levels
}

\author{
Renata Matraszek-Gawron and Barbara Hawrylak-Nowak *(D) \\ Department of Botany and Plant Physiology, Faculty of Environmental Biology, University of Life Sciences in \\ Lublin, Akademicka 15, 20-950 Lublin, Poland; renata.matraszek@up.lublin.pl \\ * Correspondence: barbara.nowak@up.lublin.pl
}

Received: 3 October 2019; Accepted: 22 October 2019; Published: 23 October 2019

\begin{abstract}
An efficient method of improving the micronutrient status of Ni-treated white mustard (Sinapis alba L.) using intensive $\mathrm{S}^{-\mathrm{SO}_{4}}$ nutrition was developed. Twelve variants of Hoagland's nutrient solution differing in the concentration of S-SO ${ }_{4}$ (standard: $2 \mathrm{mM} \mathrm{S}$, and elevated level: 6 or $9 \mathrm{mM} \mathrm{S})$ and $\mathrm{Ni}(0,0.0004,0.04$, or $0.08 \mathrm{mM} \mathrm{Ni})$ were tested. The beneficial effect of intensive $\mathrm{S}$ nutrition on Ni-stressed plants was manifested by a significant rise in the content of $\mathrm{Fe}, \mathrm{Mn}$, and $\mathrm{Zn}$, especially in the shoots. An increase was also found in the shoot $\mathrm{B}, \mathrm{Cu}$, and Mo content, whilst there were no changes in their root concentrations. Simultaneously, the shoot $\mathrm{Cl}$ concentrations dropped. The elevated level of $\mathrm{S}$ in the nutrient solution in general enhanced the translocation of $\mathrm{Fe}$, $\mathrm{Cu}, \mathrm{Mo}$, and B in Ni-exposed plants. The beneficial effect of intensive $\mathrm{S}$ nutrition on the growth and micronutrient balance of Ni-exposed plants can be at least partially related to the positive changes in root surface properties, especially in cation exchange capacity (CEC). Meanwhile both reduced glutathione (GSH) and phytochelatins (PCs) probably do not significantly contribute to Ni resistance of white mustard under intensive $S$ nutrition.
\end{abstract}

Keywords: metal toxicity; sulphur nutrition; stress mitigation; cation exchange capacity; glutathione

\section{Introduction}

Nickel, like other metallic micronutrients in plants, is a functional constituent of the enzyme systems and its role is primarily associated with the valence change. This element, at relatively low concentrations (0.001-0.01 $\mathrm{mg} \mathrm{kg}^{-1}$ dry weight; DW) is needed for the proper $\mathrm{N}$ and C metabolism [1-3] as well as for producing high-vigor viable seeds and their germination $[4,5]$. The most common visual symptoms of $\mathrm{Ni}$ deficiency are growth reduction, senescence acceleration, and leaf deformation accompanied by chlorotic and necrotic lesions as a result of Fe deficiency induced in Ni-deficient plants [6,7]. However, not Ni deficiency, but its excess and strong phytotoxic effects are the serious global problem. Nickel may easily move in the environment. Of particular concern is the increasing area of Ni-contaminated agricultural soils together with rapidly rising $\mathrm{Ni}$ concentrations deposited in agricultural soils by airborne Ni particles. Moreover, the low soil $\mathrm{pH}$ as a result of reduced soil liming as well as acid rains may cause mobilization and enhance the solubility of $\mathrm{Ni}$ compounds $[8,9]$. It has been established that the Ni content in farm soils varies in a wide range from 3 to $1000 \mathrm{mg}$ $\mathrm{kg}^{-1} \mathrm{DW}$. Most agricultural soils contain $25 \mathrm{mg} \mathrm{kg}^{-1}$; however, Ni content is very often raised, up to $26,000 \mathrm{mg} \mathrm{kg}^{-1}$ or even substantially higher, due to anthropogenic activities such as mining, smelting, burning of fossil fuels (coal and oil), use of industrial and municipal wastes (sewage sludge), as well as applications of pesticides and Ni-containing fertilizers, especially phosphates [8-12]. A strongly phytotoxic effect of high $\mathrm{Ni}$ concentrations manifests itself as growth and development inhibition 
including retarded germination, yield and quality reduction, as well as disturbances in photosynthesis, respiration, water relations, and sugar transport, which cause various ultrastructural modifications. Visual symptoms induced by the $\mathrm{Ni}$ excess include various types of leaf chlorosis, necrosis, and wilting [6,13-15]. These chlorotic and necrotic lesions are a result of altered essential nutrient uptake and translocation. Interference with nutrient homeostasis and thus improper nutrient, especially micronutrient, status within plants is mentioned as an important mechanism of Ni phytotoxicity $[16,17]$. The modifications of the mineral status of Ni-stressed plants within species and even cultivars are unpredictable and contradictory. Besides, it is very difficult to study the biological role and mechanisms of Ni toxicity due to the dual character and complicated electronic chemistry of this element. Therefore, much more information concerning phytotoxicity and tolerance can be found for other widespread toxic trace metals $(\mathrm{Cd}, \mathrm{Pb}, \mathrm{Cr}, \mathrm{Cu})$ than for $\mathrm{Ni}[18,19]$. White mustard, chosen as an object of this study, may tolerate excessive concentrations of trace metals, including Ni. This species is recognized as more sensitive to excessive amounts of $\mathrm{Ni}$ than to $\mathrm{Cu}$ or $\mathrm{Zn}[20,21]$.

White or yellow mustard (Sinapis alba L.) is believed to be native to the Mediterranean region, but nowadays is extensively cultivated throughout the world, with Canada and Nepal as the global leaders (around $52 \%$ of the world production in the 2015) as well as Ukraine, Russia, the Czech Republic, Italy, the UK, and the Netherlands as the European leaders [22]. White mustard seeds in food industry serve to produce table mustard, oil, and many kinds of spices. They are also used in the pharmaceutical and cosmetics industry. Furthermore, young fresh mustard raw leaves are used to made salad or juice [22,23]. In agriculture and horticulture, mustards are commonly used as green manure, fodder crop as well as winter or rotational cover crops in production of many species. Mustards may control weeds and a range of soil-borne pests, pathogens, and diseases. This is due to providing allelopathic compounds in the "biofumigation" process related to release of volatile toxic isothiocyanate compounds (ITCs) through the degradation of glucosinolates (GLS) [24,25].

Due to GLS synthesis in mustard, similar to the other members of the Brassicaceae family, the species is characterized by high $S$ requirement, which are at least twice as high as that of cereal crops, especially at the flowering stage, since $S$ is a constituent of sulfuric amino acids needed for the synthesis of seed proteins. This macronutrient is also an important constituent of lipids, polysaccharides, vitamins, and cofactors [26-33]. Besides building proteins and involvement in metabolism of secondary products, $\mathrm{S}$ is required for chlorophyll synthesis as well as proper cell metabolic pathways such as electron transport in Fe-S clusters, redox cycle, protein disulfide bonds. Sulphur deficiency in the environment and hence reduced yield and quality is a global problem related to progressive reduction of emissions of S compounds, common application of S-free NPK fertilizers, immobilization in soil and limited availability of $S$ to plants, and much more intensive crop production [34,35]. An adequate $S$ level is crucial not only for a proper plant growth and development, but also for enhanced resistance to various environmental stresses [36,37]. Plants have developed various strategies to cope with excess of trace metals. One of the strategies is induction of ligands synthesis, which are able to bind most trace metals in order to protect metal-target i.e., sensitive cellular organelles. Nickel is classified as a transition metal capable of binding to various types of naturally occurring phytocompounds. For instance, SH-containing ligands like reduced glutathione (GSH) or phytochelatins (PCs) form high-strength, durable complexes with trace metals. Nickel resistance is related mainly to GSH synthesis, since $\mathrm{Ni}$ is a very weak inductor of PCs synthesis. On the one hand, $\mathrm{Ni}$ is recognized as an important element for protecting plants against stressful conditions, among others, by participating in the regulation of the GSH pool involved in the defense against oxidative stress; on the other hand, $\mathrm{Ni}$ may induce oxidative stress [3,38-40].

Excessive Ni concentration disturbs the nutrient status in plants due to various unfavorable changes in their uptake and translocation $[2,11-13,15]$, and there is evidence that $S$ has a crucial role in enhancing tolerance to various types of stress [35]. Therefore, it may be possible to improve the nutrient status in Ni-stressed plants using $S$ supplementation. This concerns especially species characterized by high $S$ requirements, such as white mustard. In this study we investigated the impact of different 
S-SO $\mathrm{S}_{4}$ concentrations on the micronutrient status in white mustard under short-term Ni exposition. We hypothesized that intensive $\mathrm{S}$ nutrition may improve the growth and micronutrient status of $\mathrm{Ni}$-exposed white mustard by the modulation of selected physiological parameters of roots. It is obvious that only plant species that are able to survive in an environment containing excess of trace metals at their early (juvenile) growth stages may produce resistant and healthy adult individuals. These experiments are the part of a larger project concerning the possibility of enhancing plant resistance to stress induced by trace metals with the use of intensive $S$ nutrition.

\section{Results}

\subsection{Micronutrient Concentrations}

The concentrations of micronutrient in the roots are presented in Table 1, while micronutrients in the shoots are presented in Table 2. The root and shoot B concentrations as well as the root $\mathrm{Zn}$ and shoot $\mathrm{Cu}$ level in the intensively S-supplied ( 6 or $9 \mathrm{mM}$ ) Ni-untreated plants were higher than those at the standard $\mathrm{S}$ level. In turn, the changes in the shoot $\mathrm{Zn}$ and root $\mathrm{Cu}$ concentrations, similar to the changes in the content of $\mathrm{Fe}, \mathrm{Cl}$, and $\mathrm{Mo}$, were generally insignificant. The $\mathrm{Mn}$ concentration in plants supplied with the high $\mathrm{S}$ increased in the roots and decreased in the shoots, and these changes were more pronounced in the roots.

Increasing Ni concentrations in the nutrient solution, irrespective of the S level, generally resulted in a significant decline in Fe and B concentrations, which was much more pronounced in the shoots than in roots, and simultaneously did not change the Mo concentrations. Moreover, the statistical analysis of the main effects showed that the root $\mathrm{Cu}$ and $\mathrm{Cl}$ concentrations of Ni-exposed white mustard remained quite stable, whilst the shoot content of both these elements was substantially reduced. An exception was the decrease in the root $\mathrm{Cu}$ content recorded in plants treated with $0.04 \mathrm{mM} \mathrm{Ni}$. Simultaneously, the root and shoot Zn concentration decreased and increased, respectively, whilst the concentration of $\mathrm{Mn}$ increased in both roots and shoots.

Intensive $\mathrm{S}$ nutrition, irrespective of the $\mathrm{Ni}$ concentration in the nutrient solution, generally caused increases in the shoot and root Fe, B, and $\mathrm{Zn}$ concentrations. However, the root and shoot Fe level in plants grown at $6 \mathrm{mMS}$ and the root $\mathrm{B}$ concentration at $9 \mathrm{mM} \mathrm{S}$ did not change significantly. At the same time, root $\mathrm{Cu}$ and Mo concentrations remained quite stable, whilst their shoot concentrations were markedly elevated. In turn, the Mn concentration increased in roots and $\mathrm{Cl}$ level decreased in shoots.

The tendencies toward changes in the micronutrient concentrations for the interactions between the $\mathrm{S}$ and $\mathrm{Ni}(\mathrm{S} \times \mathrm{Ni})$ were generally similar to those above described for the main effects. However, a few differences were found. For instance, noteworthy is the decrease in the shoot $\mathrm{Mn}$ and Mo concentrations as well as the lack of significant changes in the root $\mathrm{B}$ and shoot $\mathrm{Cl}$ and $\mathrm{Zn}$ concentrations in the Ni-exposed plants grown at the standard S level. In turn, the following differences between the main effects and $\mathrm{S} \times \mathrm{Ni}$ interactions in the Ni-exposed plants supplied with extra $\mathrm{S}$, in relation to plants treated with a comparable Ni concentration grown at standard S level, were found (see Tables 1 and 2):

- $\quad$ no changes in the root Fe concentration under intensive $S$ nutrition in plants under the lowest and the highest $\mathrm{Ni}$ exposure and the Fe increase under medium $\mathrm{Ni}$ concentration,

- no changes in the root B concentration under both elevated $S$ levels,

- $\quad$ an increase in the shoot $\mathrm{Mn}$ at both the high $\mathrm{S}$ levels and a decrease in root $\mathrm{Mn}$ at the $9 \mathrm{mM} \mathrm{S} / 0.0004 \mathrm{mM}$ Ni treatment,

- $\quad$ an increase or no changes in the root $\mathrm{Zn}$ concentration at 6 and $9 \mathrm{mMS}$, respectively. 
Table 1. The concentration of micronutrients in the root biomass of white mustard grown for two weeks under different sulphur and/or nickel concentrations in the nutrient solution.

\begin{tabular}{|c|c|c|c|c|c|c|c|c|}
\hline \multicolumn{2}{|c|}{$\begin{array}{l}\text { Concentration in the } \\
\text { Nutrient Solution (mM) }\end{array}$} & \multicolumn{7}{|c|}{ Concentration of the Micronutrients in the Roots ( $\left.\mathrm{mg} \mathrm{kg}^{-1} \mathrm{DM}\right)$} \\
\hline S & $\mathrm{Ni}$ & $\mathrm{Fe}$ & B & $\mathrm{Cl}$ & $\mathrm{Cu}$ & $\mathrm{Mn}$ & Mo & $\mathrm{Zn}$ \\
\hline 2 & \multirow{3}{*}{0.00} & $1378 \pm 42.6^{\mathrm{a}}$ & $17.24 \pm 1.58^{\mathrm{c}}$ & $8485 \pm 53.87$ & $5.48 \pm 0.22^{\mathrm{ab}}$ & $47.18 \pm 1.02^{\mathrm{e}}$ & $0.642 \pm 0.093$ & $34.89 \pm 0.95^{\mathrm{d}-\mathrm{f}}$ \\
\hline 6 & & $1382 \pm 43.0^{\mathrm{a}}$ & $22.13 \pm 2.73^{\mathrm{a}}$ & $8478 \pm 70.42$ & $5.72 \pm 0.35^{\mathrm{a}}$ & $53.37 \pm 0.97^{\mathrm{bc}}$ & $0.585 \pm 0.060$ & $45.57 \pm 1.14^{\mathrm{a}}$ \\
\hline 9 & & $1377 \pm 52.2^{\mathrm{a}}$ & $20.77 \pm 1.65^{b}$ & $8498 \pm 55.39$ & $5.13 \pm 0.56^{\mathrm{a}-\mathrm{c}}$ & $55.74 \pm 0.76^{\mathrm{a}}$ & $0.663 \pm 0.074$ & $42.61 \pm 0.99^{\mathrm{ab}}$ \\
\hline 2 & \multirow{3}{*}{0.0004} & $1372 \pm 32.5^{\mathrm{a}}$ & $18.14 \pm 2.51^{\mathrm{c}}$ & $8492 \pm 97.01$ & $5.01 \pm 0.46^{\mathrm{a}-\mathrm{d}}$ & $54.81 \pm 0.84^{\mathrm{a}-\mathrm{c}}$ & $0.608 \pm 0.087$ & $36.28 \pm 1.22^{\mathrm{de}}$ \\
\hline 6 & & $1380 \pm 61.7^{a}$ & $17.29 \pm 1.67^{c}$ & $8484 \pm 41.66$ & $5.36 \pm 0.70^{\mathrm{ab}}$ & $53.78 \pm 0.66^{\mathrm{a}-\mathrm{c}}$ & $0.597 \pm 0.058$ & $40.67 \pm 1.48^{b c}$ \\
\hline 9 & & $1370 \pm 62.7^{a}$ & $17.71 \pm 2.49^{c}$ & $8503 \pm 84.72$ & $5.29 \pm 0.39^{a-c}$ & $51.13 \pm 0.80^{\mathrm{d}}$ & $0.591 \pm 0.051$ & $38.52 \pm 1.09^{b-d}$ \\
\hline 2 & \multirow{3}{*}{0.04} & $1263 \pm 21.9^{c}$ & $17.05 \pm 2.63^{c}$ & $8473 \pm 72.38$ & $4.42 \pm 0.31^{\mathrm{cd}}$ & $53.19 \pm 0.75^{\mathrm{c}}$ & $0.617 \pm 0.052$ & $31.12 \pm 1.14^{\mathrm{h}}$ \\
\hline 6 & & $1279 \pm 42.0^{c}$ & $18.09 \pm 2.57^{\mathrm{c}}$ & $8488 \pm 89.84$ & $4.73 \pm 0.66^{\mathrm{b}-\mathrm{d}}$ & $55.31 \pm 0.88^{\mathrm{ab}}$ & $0.580 \pm 0.041$ & $35.43 \pm 0.99^{\text {de }}$ \\
\hline 9 & & $1310 \pm 30.4^{b}$ & $17.42 \pm 1.66^{\mathrm{c}}$ & $8482 \pm 75.05$ & $4.16 \pm 0.54^{\mathrm{d}}$ & $54.02 \pm 0.76^{\mathrm{ac}}$ & $0.635 \pm 0.049$ & $33.74 \pm 1.16^{\mathrm{e}-\mathrm{h}}$ \\
\hline 2 & \multirow{3}{*}{0.08} & $1307 \pm 36.1^{b}$ & $18.59 \pm 1.67^{c}$ & $8500 \pm 59.32$ & $4.87 \pm 0.57^{a-d}$ & $51.04 \pm 0.64^{\mathrm{d}}$ & $0.659 \pm 0.102$ & $28.13 \pm 0.94^{\mathrm{hi}}$ \\
\hline 6 & & $1299 \pm 33.2^{b}$ & $17.35 \pm 1.48^{\mathrm{c}}$ & $8477 \pm 93.41$ & $5.07 \pm 0.61^{a-c}$ & $54.28 \pm 0.93^{\mathrm{a}-\mathrm{c}}$ & $0.668 \pm 0.044$ & $31.37 \pm 1.21^{\mathrm{f}-\mathrm{h}}$ \\
\hline 9 & & $1313 \pm 42.2^{b}$ & $18.28 \pm 2.53^{c}$ & $8492 \pm 84.85$ & $5.34 \pm 0.43^{\mathrm{ab}}$ & $52.95 \pm 0.75^{\mathrm{cd}}$ & $0.584 \pm 0.057$ & $26.48 \pm 0.87^{i}$ \\
\hline \multicolumn{9}{|c|}{ Main effects } \\
\hline & & $1330 \pm 52.4$ & $17.76 \pm 1.48^{b}$ & $8488 \pm 70.21$ & $4.95 \pm 0.37$ & $51.56 \pm 0.43^{b}$ & $0.632 \pm 0.027$ & $32.61 \pm 0.73^{c}$ \\
\hline & & $1335 \pm 41.4$ & $18.72 \pm 1.52^{a}$ & $8482 \pm 82.08$ & $5.22 \pm 0.23$ & $54.19 \pm 0.41^{a}$ & $0.608 \pm 0.024$ & $38.26 \pm 1.64^{a}$ \\
\hline & & $1342 \pm 59.0$ & $18.55 \pm 1.41^{a b}$ & $8494 \pm 70.83$ & $4.98 \pm 0.69$ & $53.46 \pm 0.48^{a}$ & $0.618 \pm 0.019$ & $35.34 \pm 0.68^{b}$ \\
\hline \multicolumn{9}{|c|}{10.001 .71} \\
\hline & & $1379 \pm 44.8^{a}$ & $20.05 \pm 1.64^{a}$ & $8487 \pm 91.37$ & $5.44 \pm 0.45^{a}$ & $52.10 \pm 0.67^{c}$ & $0.630 \pm 0.037$ & $41.02 \pm 0.70^{a}$ \\
\hline & & $1374 \pm 51.3^{a}$ & $17.71 \pm 1.58^{b}$ & $8493 \pm 72.44$ & $5.22 \pm 0.68^{a}$ & $53.24 \pm 0.48^{a b}$ & $0.599 \pm 0.018$ & $38.49 \pm 0.75^{b}$ \\
\hline & & $1283 \pm 32.4^{b}$ & $17.52 \pm 1.46^{b}$ & $8481 \pm 63.36$ & $4.44 \pm 0.47^{b}$ & $54.17 \pm 0.41^{a}$ & $0.611 \pm 0.022$ & $33.43 \pm 0.63^{c}$ \\
\hline & & $1306 \pm 42.3^{a b}$ & $18.07 \pm 1.53^{b}$ & $8490 \pm 70.09$ & $5.09 \pm 0.64^{a}$ & $52.76 \pm 0.45^{b c}$ & $0.637 \pm 0.028$ & $28.66 \pm 0.59^{d}$ \\
\hline \multicolumn{9}{|c|}{ Statistical significance } \\
\hline & & NS & * & NS & NS & * & NS & * \\
\hline & & $*$ & * & NS & $*$ & * & NS & * \\
\hline & & * & * & NS & * & * & NS & * \\
\hline
\end{tabular}

Note: The results are presented as the mean \pm SD of nine measurements (three measurements made per each of three independent repetition of the experiment over time). Means ( $\mathrm{n}=9$ ) sharing the same letter in a column do not differ significantly according to Tukey's multiple range test at $p \leq 0.05$; significant effects for the main factors and for interaction between them are indicated with asterisks $\left(^{*}\right)$; NS-non-significant. 
Table 2. The concentration of micronutrients in the shoot biomass of white mustard grown for two weeks under different sulphur and/or nickel concentrations in the nutrient solution.

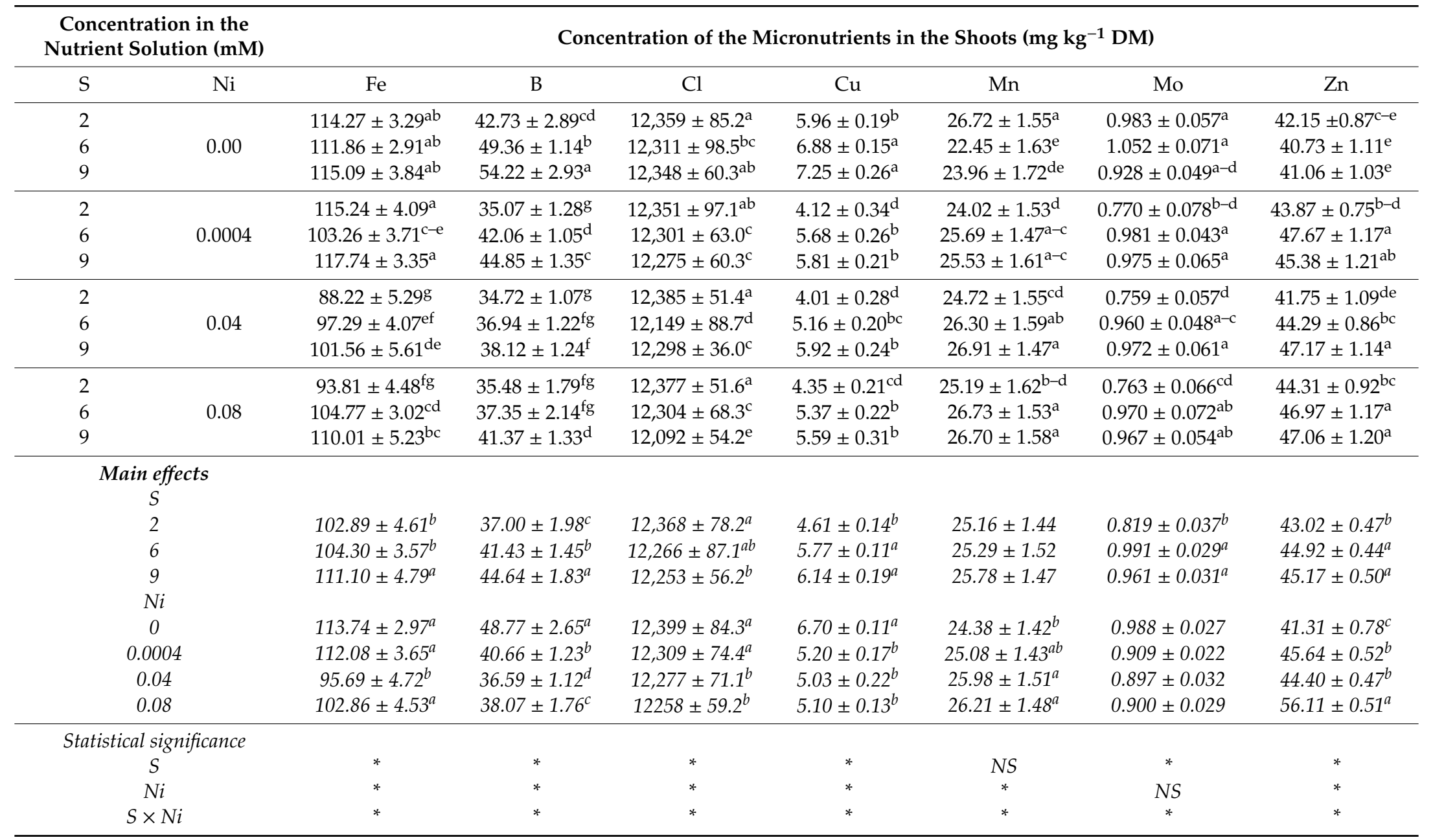

Note: For explanation see Table 1. 


\subsection{Micronutrient Translocation Factor (TF)}

Intensive $\mathrm{S}$ nutrition of plants non-exposed to $\mathrm{Ni}$ caused an increase of TF value for $\mathrm{Cu}$ (Figure $1 \mathrm{~d}$ ) and its reduction for $\mathrm{Mn}$ and $\mathrm{Zn}$ (Figure 1e,g). The Mo translocation from roots to shoots increased at $6 \mathrm{mM} \mathrm{S}$ and decreased at $9 \mathrm{mM} \mathrm{S}$ (Figure 1f). Simultaneously, the B translocation decreased at $6 \mathrm{mM} \mathrm{S}$ (Figure $1 \mathrm{~b}$ ). The presence of $\mathrm{Ni}$ in the nutrient solution at the standard $\mathrm{S}$ level severely reduced the TF value of $\mathrm{Fe}, \mathrm{B}, \mathrm{Cu}, \mathrm{Mn}$, and Mo without notable effect on $\mathrm{Cl}$ translocation (Figure 1a-f). The exception was no significant changes for the TF of Fe at the $2 \mathrm{mM} \mathrm{S} / 0.0004 \mathrm{mM} \mathrm{Ni}$ treatment. Simultaneously, the $\mathrm{TF}$ value of $\mathrm{Zn}$ increased at the highest $\mathrm{Ni}$ concentration used, compared to the Ni-untreated plants (Figure 1g).

Supplementation with $S$ of the Ni-exposed plants, in relation to the standard $2 \mathrm{mM} S$ level, significantly elevated the TF of $\mathrm{B}, \mathrm{Cu}$, and Mo (Figure $1 \mathrm{~b}, \mathrm{~d}, \mathrm{f}$ ) and did not notably affect the TF value for the $\mathrm{Cl}, \mathrm{Mn}$, and $\mathrm{Zn}$ (Figure 1c,e,g). Only the TF values of Mn and $\mathrm{Zn}$ at the $9 \mathrm{mM} \mathrm{S/0.0004} \mathrm{mM} \mathrm{Ni}$ and $9 \mathrm{mM} \mathrm{S} / 0.08 \mathrm{mM} \mathrm{Ni}$ treatments, respectively, were significantly higher than TF values found for the comparable Ni concentrations in the medium under the standard $\mathrm{S}$ level (Figure 1e,g). The lack of significant changes in TF value of B at the $6 \mathrm{mM} \mathrm{S} / 0.04 \mathrm{mM}$ Ni treatment was an exception (Figure $1 \mathrm{~b}$ ). In turn, the TF of Fe under the lowest Ni concentration used decreased at $6 \mathrm{mM} \mathrm{S}$ and did not change at $9 \mathrm{mMS}$, but increased under intensive $S$ nutrition at the higher Ni concentrations $(0.04$ and $0.08 \mathrm{mM}$; Figure 1a).

\subsection{Total Surface Charge $\left(Q_{t o t}\right)$ and Cation Exchange Capacity (CEC)}

The changes in $\mathrm{Q}_{\text {tot }}$ and CEC are presented in Figure 2a,b. The CEC values at $2 \mathrm{mM}$ S were markedly lower (by 29-40\%) in roots of plants treated with Ni than in those non-exposed to this metal. Under these conditions the $Q_{\text {tot }}$ decreased significantly (by 27\%) only at the highest Ni concentration. When the Ni-exposed plants were supplied with extra $\mathrm{S}$ at the concentration of $6 \mathrm{mM}$ the CEC increased by $80-89 \%$ in comparison to plants grown at standard $S$ level. Meanwhile, the $Q_{\text {tot }}$ value increased significantly for plants treated with $0.04 \mathrm{mM} \mathrm{Ni}$ supplied with $6 \mathrm{mMS}$ and plants treated with $0.08 \mathrm{mM}$ $\mathrm{Ni}$ and supplied with 6 or $9 \mathrm{mM} \mathrm{S}$. In general, the impact of the highest concentration of S on CEC and $Q_{\text {tot }}$ was negative at the lowest and moderate Ni concentrations used and their values were significantly reduced. On the other hand, under the highest $\mathrm{Ni}$ concentration the intensive $\mathrm{S}$ nutrition at $9 \mathrm{mM}$ caused an increase in both CEC and $Q_{\text {tot }}$ values. It is worth noting that the CEC in plants exposed to $0.08 \mathrm{mM} \mathrm{Ni}$ increased almost twice under intensive $S$ nutrition in comparison to standard S level.

\subsection{GSH and PCs Accumulation in Roots}

The changes in root GSH concentrations were ambiguous (Figure 3a). In general, in Ni-exposed plants an elevated GSH accumulation was found, when we compare the level of this compound in the control plants and in these grown under presence of $\mathrm{Ni}$ at the appropriate $\mathrm{S}$ levels. The intensive $\mathrm{S}$ nutrition of Ni-untreated plants resulted in the decrease in GSH accumulation. At $6 \mathrm{mM} \mathrm{S}$, no significant changes in GSH content were found at any of the tested Ni concentrations, in comparison to 2 mM S. In turn, the extra S supply at the concentration of $9 \mathrm{mM}$ increased the GSH concentration in the plants treated with 0.0004 or $0.08 \mathrm{mM} \mathrm{Ni}$, but decreased in those exposed to $0.04 \mathrm{mM} \mathrm{Ni}$.

In roots of white mustard only small amounts of PCs 2 were found. Phytochelatins were not detectable or only trace concentrations of PCs 2 appeared in the roots of plants grown at $2 \mathrm{mM} \mathrm{S}$ without Ni or at the lowest Ni concentration. The enhanced concentrations of PCs 2 in the root tissues were detected with the increasing concentration of Ni. However, the intensified S nutrition significantly enhanced PCs 2 accumulation only at the lowest and the medium Ni concentration. Under the highest $\mathrm{Ni}$ exposition, the PCs 2 concentration decreased in comparison to the standard S level (Figure 3b). 


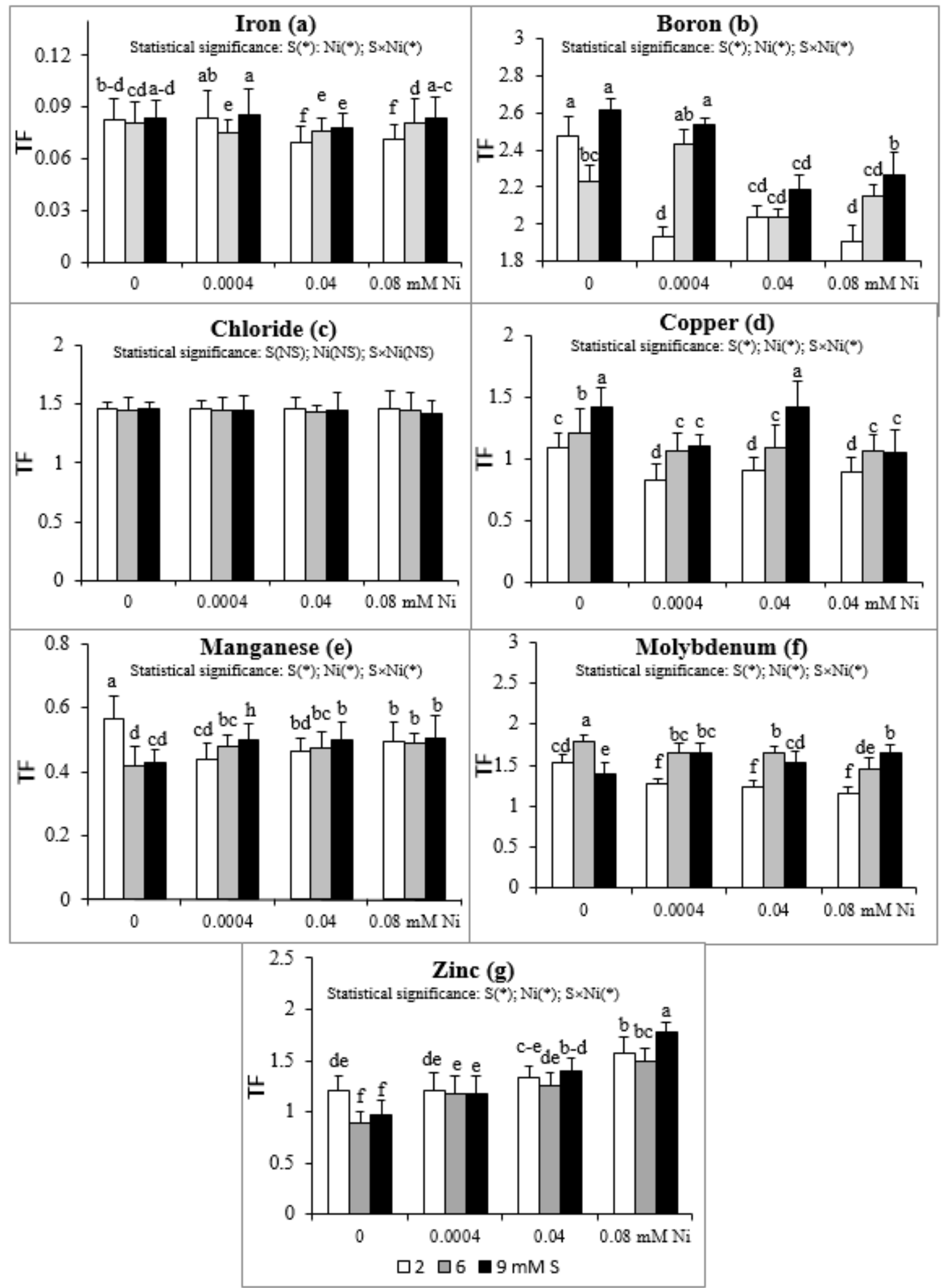

Figure 1. Translocation factor (TF) of micronutrients: (a) iron, (b) boron, (c) chloride, (d) copper, (e) manganese, (f) molybdenum, (g) zinc in white mustard "Rota" grown under different sulphur and/or nickel concentrations in the nutrient solution. Mean values $(n=9)$ followed by the same letter are not significant at 0.05 probability level based on Tukey's honestly significance tests. Asterisks indicate significant effects for main factors and interactions between them. 


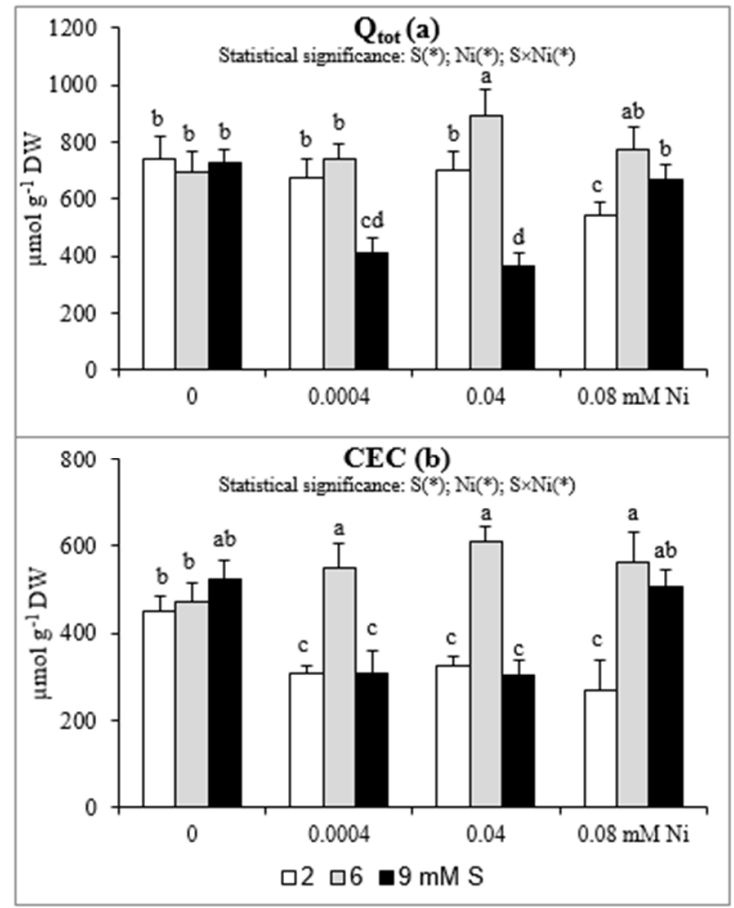

Figure 2. The (a) total surface charge $\left(Q_{\text {tot }}\right)$ and (b) cation exchange capacity $(C E C)$ in white mustard "Rota" grown under different sulphur and/or nickel concentrations in the nutrient solution. Mean values $(n=9)$ followed by the same letter are not significant at 0.05 probability level based on the Tukey's honestly significance tests. Asterisks indicate significant effects for main factors and interactions between them.

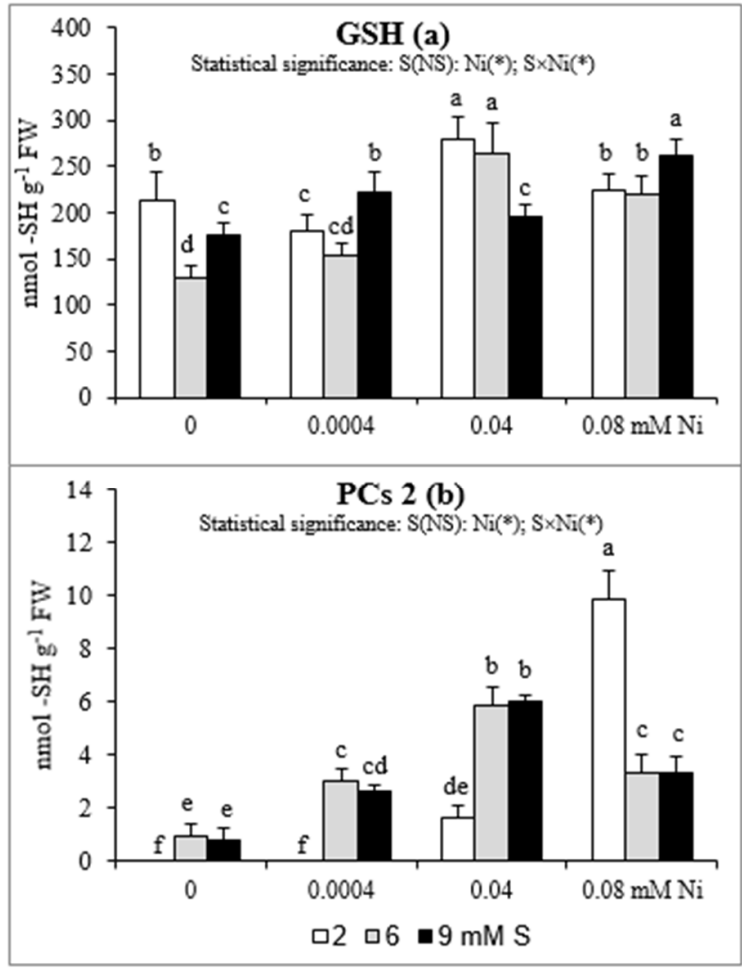

Figure 3. Concentrations of (a) reduced glutathione (GSH) and (b) phytochelatins (PCs) in white mustard "Rota" grown under different sulphur and/or nickel concentrations in the nutrient solution. Mean values $(n=9)$ followed by the same letter are not significant at 0.05 probability level based on Tukey's honestly significance tests. Asterisks indicate significant effects for main factors and interactions between them. 


\subsection{Root and Shoot Biomass}

The results of the influence of differentiated $\mathrm{Ni}$ and $\mathrm{S}$ concentrations in the nutrient solution on shoot and root DW are presented in Figure 4. Both the shoot and root biomass of plants treated with 0.04 or $0.08 \mathrm{mM}$ Ni was reduced. Meanwhile, the lowest concentration of this element has no effect on plant growth. In mustard exposed to $0.04 \mathrm{mM} \mathrm{Ni}$, the intensive $S$ nutrition at $6 \mathrm{mM}$, in comparison to the standard S level, caused an increase in the shoot DW, which was not statistically different from Ni-untreated plants. However, this phenomenon did not occur at $9 \mathrm{mM} \mathrm{S}$ and under the highest Ni concentration used (Figure $4 \mathrm{a}$ ). In turn, in mustard not subjected to $\mathrm{Ni}$, the extra $\mathrm{S}$ supply induced a $45-50 \%$ increase in root DW compared to the standard S level. Such a trend was also observed in the presence of $\mathrm{Ni}$, but it was not statistically confirmed. The exception was a significant increase in root DW of plants treated with $0.04 \mathrm{mM}$ Ni under the influence of $9 \mathrm{mM} \mathrm{S}$ (Figure $4 \mathrm{~b}$ ).

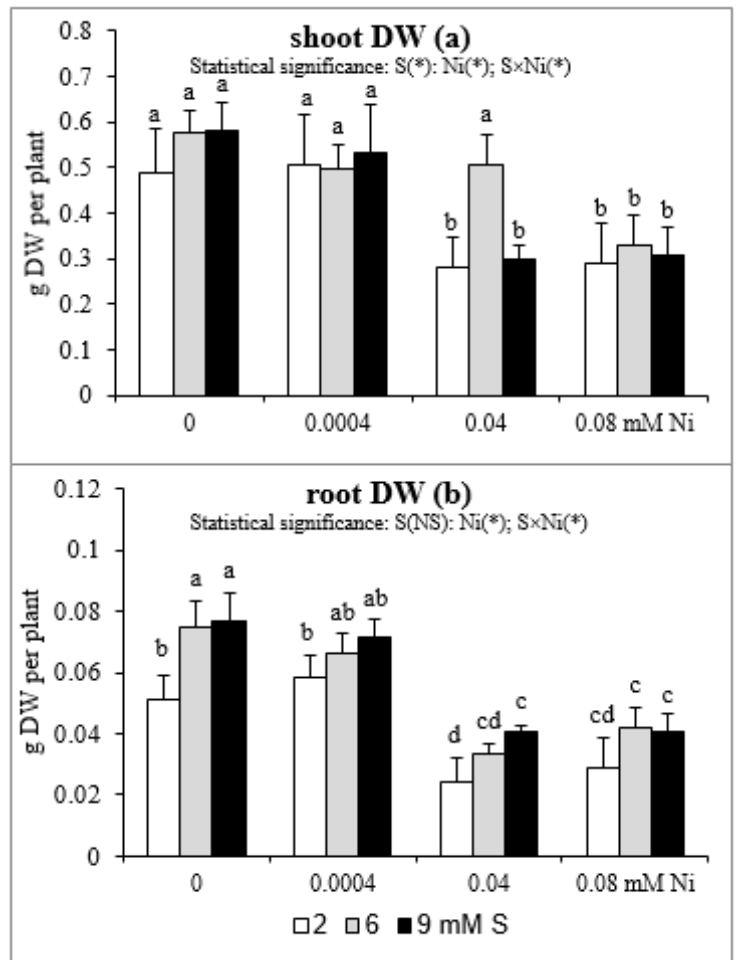

Figure 4. The dry weight (DW) of (a) shoots and (b) roots of white mustard "Rota" grown under different sulphur and/or nickel concentrations in the nutrient solution. Mean values $(n=36)$ followed by the same letter are not significant at 0.05 probability level based on Tukey's honestly significance tests. Asterisks indicate significant effects for main factors and interactions between them.

\section{Discussion}

The lowest $\mathrm{Ni}$ concentration used $(0.0004 \mathrm{mM})$ is claimed to be the highest value acceptable for the ground water and soil solution [6,41-43]. That means that the presence of higher concentrations of this metal, including those examined in our study ( 0.04 and $0.08 \mathrm{mM})$, requires implementation of conservation measures. The impact of $\mathrm{Ni}$ on the white mustard micronutrient status under the standard $S$ dose $(2 \mathrm{mM})$ are in agreement with the widely known statement that interference with other essential metal ions are an indirect pathway of $\mathrm{Ni}$ phytotoxicity. It was also confirmed that Ni-induced changes in the nutrient bioconcentrations are not only species-specific, but also unpredictable and contradictory. Additionally, these changes may be different in the roots and aboveground parts of plants $[13,15,44]$. The phenomenon of Ni-induced alterations in essential nutrient absorption, uptake, and transport and hence the disturbance in ionic homeostasis is a consequence of competition between $\mathrm{Ni}^{2+}$ and other cations $\left(\mathrm{Cu}^{2+}, \mathrm{Fe}^{2+}, \mathrm{Mn}^{2+}\right.$, and $\left.\mathrm{Zn}^{2+}\right)$ for common binding sites as a result of similar characteristics, 
including comparable ionic radii [44-46]. Passive diffusion and active transport are recognized as two main mechanisms of $\mathrm{Ni}$ ions uptake by plants. Absorption of soluble Ni compounds occurs passively via a cation transport system. Chelated Ni compounds are taken up through secondary active-transport-mediated means, i.e., permeases. In turn, endocytosis is recognized as a mechanism through which insoluble Ni compounds primarily enter plant root cells. After absorption by roots, $\mathrm{Ni}$ transport to the shoot occurs very easily via the xylem. The processes of $\mathrm{Ni}$ transport and retranslocation are strongly regulated by metal-ligand complexes (nicotianamine, histidine, and organic acids) and by some specific Ni-binding proteins $[6,13,19]$. Moreover, Ni uptake and translocation occur with involvement of a Zn/Fe ZRT1/IRT1-ZIP transporter and a Mn ion transporter NRAMP [19,43,44]. The antagonism between $\mathrm{Ni}^{2+}$ ions and $\mathrm{Cu}^{2+}$ and $\mathrm{Zn}^{2+}$ ions suggests that these three elements are absorbed at the same site on the transporter [44]. Hence, the decreased $\mathrm{Fe}, \mathrm{Zn}$, and $\mathrm{Cu}$ concentrations in the mustard biomass, manifested as various types of chloroses, were also recorded by other researchers in many other plant species [41,45]. The results of the present study indicate antagonism between $\mathrm{Ni}$ and $\mathrm{Cl}$ and between $\mathrm{Ni}$ and Mo. It should be remembered that $\mathrm{Ni}$ may not only compete with essential nutrients, mainly $\mathrm{Fe}, \mathrm{Zn}$, and $\mathrm{Cu}$, but also inhibit their functions. Nickel may replace the essential metal of metalloproteins and bind the residues of non-metalloenzymes. The binding of $\mathrm{Ni}$ ions outside the catalytic site of an enzyme induces allosteric modulation and, hence, the inhibition of the enzyme. Besides the above-mentioned indirect effect of Ni on enzyme activity, i.e., competitive inhibition of nutrient absorption and transport, a direct mechanism associated with strong affinity of $\mathrm{Ni}$ for the functional $-\mathrm{SH}$ groups of proteins is also known $[6,13,19]$. Moreover, the Ni-induced changes in the micronutrient status recorded in the present study may be explained by the disturbances in the cell membrane permeability caused by changes in the composition of sterols and phospholipids and changes in the structure and/or activity of cell membrane enzymes, mainly the $\mathrm{H}^{+}$-ATPase, which plays a key role in the active uptake and transport of essential nutrients $[8,15,19]$.

The standard $S$ concentration $(2 \mathrm{mM})$ used in our experiments is recognized as a moderate level for this macronutrient. The $\mathrm{S}_{-} \mathrm{SO}_{4}{ }^{2-}$ concentration in the natural environment, i.e., unpolluted with trace metals, in arid regions and in soil solutions with residues of sulfide ore mine is in the range of 0.16-7, 3-16, and 13-110 $\mathrm{mM}$, respectively [46]. Our study concerning the micronutrient bioconcentration under high S-SO $\mathrm{SO}_{4}$ levels ( 6 or $9 \mathrm{mMS}$ ) in mustard grown without Ni showed a synergistic effect between $\mathrm{S}$ and $\mathrm{B}, \mathrm{S}$ and $\mathrm{Cu}$, and $\mathrm{S}$ and $\mathrm{Zn}$. Simultaneously, an antagonistic relationship between $\mathrm{S}$ and $\mathrm{Cl}$ was found. In turn, the $S$ and $M n$ relationships were antagonistic at $6 \mathrm{mMS}$ and synergistic at $9 \mathrm{mMS}$. It is claimed that an optimal S level increases the uptake of $\mathrm{Mn}$ and $\mathrm{Zn}$ [47]. The tendencies of changes in the root and shoot concentration of $\mathrm{Mn}, \mathrm{Cu}$, and $\mathrm{Zn}$ under intensive $\mathrm{S}$ nutrition in Ni-untreated white mustard were similar to those noted for this species in a field experiment of Jankowski et al. [48]. In their research the content of these three micronutrients in roots and shoots of Indian mustard was not affected by $\mathrm{S}$ fertilization, except for the $\mathrm{Cu}$ decrease in the shoots. However, in this study, the content of the other micronutrients in examined mustard species was not estimated. Moreover, in our previous study, an increase in the all macronutrient concentrations in roots and the $\mathrm{S}, \mathrm{K}$, and Ca level in shoots in Ni-exposed mustard supplied with extra S was found [49].

Taking into account the TF value, it may be concluded that white mustard has a strong ability to translocate $\mathrm{B}, \mathrm{Cl}, \mathrm{Mo}$, and $\mathrm{Zn}$ from roots to shoots $(\mathrm{TF}>1)$ and a weak ability to translocate $\mathrm{Fe}$ and $\mathrm{Mn}(\mathrm{TF}<1)$. This tendency was generally revealed irrespective of both the experimental factors, i.e., the $\mathrm{S}$ and Ni concentrations in the nutrient solution. Only the intensive $\mathrm{S}$ nutrition of Ni-untreated plants, compared to the standard $\mathrm{S}$ dose, strongly limited the translocation of $\mathrm{Zn}$, reducing the $\mathrm{Zn}$ $\mathrm{TF}$ below 1 . The $\mathrm{Cu}$ transfer within organs depended on the $\mathrm{S}$ and $\mathrm{Ni}$ concentrations in the nutrient solution. The Ni-exposed plants growing at $2 \mathrm{mM} \mathrm{S}$ showed a Cu TF value lower than 1 (about 0.9 ), in comparison with values exceeding 1 in plants grown without $\mathrm{Ni}$. This implies that the Ni presence in the nutrient solution containing standard S levels reduced the $\mathrm{Cu}$ translocation. Simultaneously, the intensive $\mathrm{S}$ nutrition of Ni-treated mustard enhanced the ability to transfer $\mathrm{Cu}$ to shoots $(\mathrm{Cu}$ TF higher 
than 1). The micronutrient TF value obtained in our studies oscillated within the range of $0.070-0.086$ (Fe), 1.91-2.611 (B), 1.42-1.46 (Cl), 0.82-1.41 (Cu), 0.42-0.57 (Mn), 1.16-1.80 (Mo), and 0.89-1.58 (Zn).

The electric charge is most frequently studied root surface property to describe the root CEC, its changes with soil $\mathrm{pH}$, balance of plant cations of different valence and toxicity of trace metals. Electric charge of the root compartments is dominated by negatively charged groups, thus positively charged cations, including essential nutrients, accumulate near the roots surface [50]. In our study we have noticed a positive effect of intensive $S$ nutrition of Ni-exposed plants on the studied properties of roots ( $Q_{\text {tot }}$ and CEC), especially at $6 \mathrm{mM} \mathrm{S}$. The beneficial effect of extra S supply of Ni-treated mustard on the changes in the studied root properties may contribute to a better uptake of micronutrients and thus positively affect the mineral status of plants, which consequently stimulates their growth. On the other hand, in plants grown at $9 \mathrm{mM} \mathrm{S}$, the values of $Q_{\text {tot }}$ and CEC decreased at 0.004 and $0.04 \mathrm{mM}$ $\mathrm{Ni}$, but increased at $0.08 \mathrm{mM} \mathrm{Ni}$ in comparison to those non-treated with $\mathrm{Ni}$. We suppose that under high $\mathrm{Ni}$ bioconcentration, the higher $\mathrm{S}$ levels can be required to abolish toxic effect of Ni to the studied root parameters.

The antioxidant defense is believed to play a key role in the Ni tolerance, as the oxidative stress induction and the disturbances in the nutrient status are the major mechanism of the phytotoxicity of this element [13]. Also, there is no doubt that Ni-tolerance is linked to S metabolism, primarily with high levels of O-acetyl-L-serine (OAS), Cys, and GSH associated with the high activity of Ser acetyl transferase (SAT). Nickel is recognized as an element with strong ability to bind to various types of chelating agents, especially S-donor ligands rich in highly reactive $\mathrm{S}$ functional groups. However, $\mathrm{Ni}$ is recognized as a weak PCs inductor [4,6,51-53], which has been also confirmed in our study. Although the amount of PCs in plants exposed to Ni was not high, but in the presence of this metal the level PCs 2 significantly increased and the intensive S nutrition enhanced PCs 2 accumulation under the lowest and moderate $\mathrm{Ni}$ exposure. On the other hand, there are strong evidence that Ni may play a role in plant response to stressful conditions by decreasing the level of methylglyoxal (MG; a toxic, mutagenic alpha-ketoaldehyde) as well as participating in the regulation of the GSH homeostasis. In the degradation pathway of MG are involved glyoxalases I and II (GLY-I and II) and recently it was found that Ni ions may activate GLY-I in plants. The GLY-I dependence on Ni may play an additional role in the regeneration of GSH $[3,54]$. In our study the concentrations of GSH at the standard S level increased under moderate Ni exposure but not under both the lowest and the highest concentrations of this metal. We suppose that the concentration of $0.0004 \mathrm{mM} \mathrm{Ni}$ could be too low to effectively induce GSH accumulation but the concentration $0.08 \mathrm{mM}$ Ni could have an adverse effect on GLY-I activity and therefore no increase in GSH concentration was found. The intensive S nutrition at $9 \mathrm{mM} \mathrm{S}$ caused enhanced accumulation of GSH only under the lowest and the highest Ni exposure. This effect was not observed at $6 \mathrm{mM} \mathrm{S}$. Therefore, the beneficial effect of intensive $S$ fertilization of Ni-stressed white mustard, which manifested itself as a rise in the $\mathrm{Fe}, \mathrm{Mn}$, and $\mathrm{Zn}$ bioconcentration, especially in the shoot biomass, is probably related to positive changes in root surface property as CEC, but not with an increase in GSH or PC synthesis in root tissues.

\section{Materials and Methods}

\subsection{Plant Material and Growth Conditions}

The biological object of the study was white mustard (Sinapis alba L.) "Rota" (Brassicaceae). Seven-day-old homogenous, healthy seedlings obtained from seeds germinated on quartz sand moistened with distilled water were transferred to $1 \mathrm{~L}$ glass jars (two plants per each jar) filled with full-strength Hoagland's solution No. 2 with different levels of $S$ and Ni. A combination of three $S$ levels (standard: $2 \mathrm{mMS}$, and intensive: 6 or $9 \mathrm{mM} \mathrm{S}$; sulfate VI $\left(\mathrm{S}_{-} \mathrm{SO}_{4}\right)$ ) and four Ni concentrations $\left(0,0.0004,0.04\right.$, and $\left.0.08 \mathrm{mM} \mathrm{Ni} ; \mathrm{NiCl}_{2}\right)$ was used to arrange the experimental treatments. In all experimental treatments, the standard $\mathrm{S}$ dose $(2 \mathrm{mM})$ was supplied as $\mathrm{MgSO}_{4}$ and supplemented with corresponding amounts of $\mathrm{Na}_{2} \mathrm{SO}_{4}$. The dose of $\mathrm{S}$ applied as $\mathrm{Na}_{2} \mathrm{SO}_{4}$ for the level of 2,6, and $9 \mathrm{mM}$ 
were 0,4 , and $7 \mathrm{mM}$, respectively. In each treatment, the levels of $\mathrm{Na}$ and $\mathrm{Cl}$ were equalized and the $\mathrm{pH}$ of the nutrient solution was set at 5.8-6.0 by adding appropriate amounts of diluted solutions of $\mathrm{NaCl}$ or $\mathrm{HCl}$. The plants were cultured in a controlled-climate vegetation room at 14-h day length, PPF of $250-270 \mu \mathrm{mol} \times \mathrm{m}^{-2} \times \mathrm{s}^{-1}$ at the level of the tops of the plants, temperature $25 / 20{ }^{\circ} \mathrm{C}$ (day/night), and relative air humidity of 50-60\%. The nutrient solution was aerated for 15 min. every three days and replenished with a fresh nutrient solution when the medium level was depleted to ca. $70 \%$ of the initial level. After 14 days of vegetation under the differentiated S and Ni concentrations, the plants were harvested and subjected to the analysis.

\subsection{Determination of Biomass and Micronutrient Concentrations}

The roots and shoots of twelve randomly selected plants were dried in a forced air oven at $105^{\circ} \mathrm{C}$ for $48 \mathrm{~h}$, their dry weight (DW) were determined, and the samples were subjected to the analysis of the micronutrient concentration. The dry plant samples were ground to form a powder using a laboratory grinding mill. The total content of $\mathrm{Fe}, \mathrm{Mn}, \mathrm{Zn}, \mathrm{Mo}$, and $\mathrm{Cu}$ in roots and shoots were analyzed by atomic-absorption spectrophotometry (AAS) after wet mineralization with sulfuric acid (VI) and perhydrol $[55,56]$. To measure the B concentration, the Azomethine-H method was employed and the absorbance was read by spectrophotometry at $410 \mathrm{~nm}$ [57]. The $\mathrm{Cl}$ concentration was determined by the nephelometric method using nitric acid and silver nitrate [58]. The data obtained were used to calculate the value of the translocation factor (TF) of micronutrients (defined as a quotient of concentration of a given element in shoots and its concentration in the roots).

\subsection{Determination of CEC and $Q_{\text {tot }}$ by Potentiometric Titration}

The values of CEC under differentiated experimental conditions were determined using potentiometric titration described in detail by Szatanik-Kloc et al. [50]. In brief, the fresh roots were placed in a ventilated room at $30^{\circ} \mathrm{C}$ for $48 \mathrm{~h}$. Then, a suspension of plant roots equilibrated overnight with $1 \mathrm{M} \mathrm{L}^{-1} \mathrm{NaCl}$ was adjusted to $\mathrm{pH}=3.0$ until the $\mathrm{pH}$ was stable over the next 5 min and titrated automatically (Titrino $702 \mathrm{MS}$, Metrohm AG, Switzerland) by 60 s increments of $1 \mu \mathrm{L}$ $0.100 \mathrm{M} \mathrm{L}^{-1}$ sodium hydroxide solution to $\mathrm{pH}=10$. The surface charge at $\mathrm{pH}=7$ was taken as the root CEC and the charge at $\mathrm{pH}=10$ was considered as the total surface charge $\left(\mathrm{Q}_{\text {tot }}\right)$.

\subsection{Determination of $\gamma$-Glu-Cys Peptides by HPLC Method}

The determine the GSH and PCs concentrations the root samples were weighted and ground in an ice-cooled mortar with a double volume of $0.1 \mathrm{M} \mathrm{HCl}$. The crude assay solution was obtained by homogenate centrifugation at $14000 \mathrm{rpm}$ at $4{ }^{\circ} \mathrm{C}$ (3 times by $5 \mathrm{~min}$ ). Beckman chromatograph (model 126/166) with Supelco precolumn $(4.6 \times 10 \mathrm{~mm})$ and column $(4.6 \times 250 \mathrm{~mm})$ (both filled with Ultrasphere $\mathrm{C} 18)$ were used. The peptide solution $(100 \mu \mathrm{L})$ was separated in a linear gradient $(0-20 \%)$ of acetonitrile (ACN) in $0.05 \%$ trifluoroacetic acid (TFA) and was subjected to a post-column reaction with $200 \mu \mathrm{M}$ 5,5'-dithiobis-2-nitrobenzoic acid (DTNB) in the $0.05 \mathrm{M}$ potassium-phosphate buffer ( $\mathrm{pH}$ =7.6). The absorbance of the resulted reaction products was measured at $405 \mathrm{~nm}$ using a Beckman detector (model 166). The chromatograms were analysed using Karat 7.0 software (Beckman).

\subsection{Statistical Analysis}

The results were processed statistically using analysis of variance (ANOVA) for a two-factor experiment ( 3 levels of $\mathrm{S}$ and 4 concentrations of $\mathrm{Ni}$ in the nutrient solution) established in a completely randomized design, using Statistica 9.0 software. Each of the twelve experimental treatments included twenty replications ( 20 jars with 2 plants in each) and the whole experiment was repeated independently three times under the same conditions. This means that each of the twelve experimental treatments included in total 60 jars and 120 plants. The main effects of the S level and Ni concentration were compared using Tukey's multiple comparison test at the significance level $p \leq 0.05$. The comparison of the values within the same treatment as well as the mean values in each of the twelve treatments 
collected from each of the three independent replicates of the experiment over the time did not show statistically proven differences.

\section{Conclusions}

The results from the present study show that it is possible to prevent to some extent unfavorable changes in the micronutrient status of the white mustard "Rota" exposed to Ni (0.0004-0.08 mM) with the use of intensive $\mathrm{S}^{-\mathrm{SO}_{4}}$ nutrition ( 6 or $9 \mathrm{mM} \mathrm{S}$ ). Generally, an increase in the $\mathrm{Fe}, \mathrm{Mn}$, and Zn bioconcentrations, especially in the shoots, were found in Ni-treated plants supplied with extra $\mathrm{S}$. The elevated concentrations of shoot $\mathrm{B}, \mathrm{Cu}$, and $\mathrm{Mn}$ were also revealed, without changes in their root concentrations. Simultaneously, the shoot $\mathrm{Cl}$ concentrations decreased. Furthermore, intensive $\mathrm{S}$ nutrition of Ni-exposed mustard, in relation to the standard $2 \mathrm{mM} \mathrm{S}$ dose, in general, enhanced the translocation of $\mathrm{Fe}, \mathrm{Cu}, \mathrm{Mo}$, and $\mathrm{B}$ from roots to shoots. The improved micronutrient status of Ni-treated mustard supplied with extra $S$ can be related to positive changes in total surface charge and cation exchange capacity of roots. However, an increase in the shoot biomass was noted only at $6 \mathrm{mM} \mathrm{S}$ in plants exposed to $0.04 \mathrm{mM} \mathrm{Ni}$. These results contribute to the knowledge concerning mechanisms employed by plants intensively supplied with $\mathrm{S}$ to cope with $\mathrm{Ni}$ stress. The present studies offer an opportunity to increase the resistance of white mustard to $\mathrm{Ni}$ excess using an intensified $\mathrm{S}$ nutrition. These methods are quite promising and effective, easy to apply, as well as sustainable and safe for the environment. It may find practical application, which is especially important for farmers and horticulturalists, but needs further confirmation under field conditions.

Author Contributions: Conceptualization, R.M.-G., B.H.-N.; methodology, R.M.-G.; software, R.M.-G.; validation, R.M.-G., B.H.-N.; investigation, R.M.-G.; writing-original draft preparation, R.M.-G.; writing-review and editing, B.H.-N.; visualization, B.H.-N.; funding acquisition, R.M.-G., B.H.-N.

Funding: This research was financially supported by the statutory funds (OKA/DS/3, Department of Plant Physiology, University of Life Sciences in Lublin) from the Polish Ministry of Science and Higher Education.

Acknowledgments: We thank the employees of Department of Plant Physiology of Maria Curie Sklodowska University (Prof. Małgorzata Wójcik, Prof. Sławomir Dresler) and Institute of Agrophysics PAS (Prof. Alicja Szatanik-Kloc) for their technical support.

Conflicts of Interest: The authors declare no conflict of interest.

\section{References}

1. Ragsdale, S.W. Nickel-based enzyme systems. J. Biol. Chem. 2009, 284, 18571-18575. [CrossRef] [PubMed]

2. Poonkothai, M.; Shyamala Vijayavathi, B. Nickel as an essential element and a toxicant. Int. J. Environ. Sci. 2012, 1, 285-288.

3. Fabiano, C.C.; Tezotto, T.; Favarin, J.L.; Polacco, J.C.; Mazzafera, P. Essentiality of nickel in plants: A role in plant stresses. Front. Plant Sci. 2015, 6, 754. [CrossRef] [PubMed]

4. Bhatia, N.P.; Nkang, A.E.; Walsh, K.B.; Baker, A.J.; Ashwath, N.; Midmore, D.J. Successful seed germination of the nickel hyperaccumulator Stackhousia tryonii. Ann. Bot. 2005, 96, 159-163. [CrossRef]

5. Polacco, J.C.; Mazzafera, P.; Tezotto, T. Opinion: Nickel and urease in plants: Still many knowledge gaps. Plant Sci. 2013, 199, 79-90. [CrossRef]

6. Ahmad, M.S.A.; Ashraf, M. Essential roles and hazardous effects of nickel in plants. Rev. Environ. Contam. Toxicol. 2011, 214, 125-167. [CrossRef]

7. López, M.Á.; Magnitski, S. Nickel: The last of the essential micronutrients. Agron. Colomb. 2011, $29,49-56$.

8. Bhalerao, S.A.; Sharma, A.S.; Poojari, A.C. Toxicity of nickel in plants. Int. J. Pure Appl. Biosci. 2015, 3, 345-355.

9. Pavlovkin, J.; Fiala, R.; Čiamporová, M.; Martinka, M.; Repka, V. Impact of nickel on grapevine (Vitis vinifera L.) root plasma membrane, ROS generation, and cell viability. Acta Bot. Croat. 2016, 75, 25-30. [CrossRef]

10. Nieminen, T.M.; Ukonmaanaho, L.; Rausch, N.; Shotyk, W. Biogeochemistry of nickel and its release into the environment. In Nickel and Its Surprising Impact in Nature, 1st ed.; Sigel, A., Sigel, H., Sigel, R.K.O., Eds.; John Wiley \& Sons: Chichester, UK, 2007; pp. 1-30. [CrossRef] 
11. Sreekanth, T.V.M.; Nagajyothi, P.C.; Lee, K.D.; Prasad, T.N.V.K.V. Occurrence, physiological responses and toxicity of nickel in plants. Int. J. Environ. Sci. Technol. 2013, 10, 1129-1140. [CrossRef]

12. Harasim, P.; Filipek, T. Nickel in the environment. J. Elem. 2015, 20, 525-534. [CrossRef]

13. Chen, C.; Huang, D.; Liu, J. Functions and toxicity of nickel in plants: Recent advances and future prospects. Clean Soil Air Water 2009, 37, 304-313. [CrossRef]

14. Shafeeq, A.; Butt, Z.A.; Muhammad, S. Response of nickel pollution on physiological and biochemical attributes of wheat (Triticum aestivum L.) var. Bhakar-02. Pak. J. Bot. 2012, 44, 111-116.

15. Hussain, M.B.; Ali, S.; Azam, A.; Hina, S.; Farooq, M.A.; Ali, B.; Bharwana, S.A.; Gill, M.B. Morphological, physiological and biochemical responses of plants to nickel stress: A review. Afr. J. Agric. Res. 2013, 8, 1596-1602. [CrossRef]

16. Ghasemi, R.; Ghaderian, S.M.; Krämer, U. Interference of nickel with copper and iron homeostasis contributes to metal toxicity symptoms in the nickel hyperaccumulator plant Alyssum inflatum. New Phytol. 2009, 184, 566-580. [CrossRef] [PubMed]

17. Yadav, S.S.; Shukla, R.; Sharma, Y.K. Nickel toxicity on seed germination and growth in radish (Raphanus sativus) and its recovery using copper and boron. J. Environ. Biol. 2009, 30, 461-466.

18. Sengar, R.S.; Gupta, S.; Gautam, M.; Sharma, A.; Sengar, K. Occurrence, uptake, accumulation and physiological responses of nickel in plants and its effects on environment. Res. J. Phytochem. 2008, 2, 44-60. [CrossRef]

19. Yusuf, M.; Fariduddin, Q.; Hayat, S.; Ahmad, A. Nickel: An overview of uptake, essentiality and toxicity in plants. Bull. Environ. Contam. Toxicol. 2011, 86, 1-17. [CrossRef]

20. Stanisławska-Głubiak, E.; Korzeniowska, J. Tolerance of white mustard (Sinapis alba L.) to soil pollution with several heavy metals. Ecol. Chem. Eng. Ser. A 2011, 18, 445-450.

21. Putnik-Delić, M.I.; Maksimović, I.V.; Gani-Novaković, I.; Zeremski, T.; Marjanović-Jaromela, A. The effect of Ni concentration of the most abundant essential cations in several Brassica species. J. Nat. Sci. 2014, 126, 15-23. [CrossRef]

22. Manohar, P.; Ram; Pushpan, R.; Rohini, S. Mustard and its uses in Ayurveda. Indian J. Tradit. Knowl. 2009, 8, 400-404.

23. Damian, C. Physical properties of mustard seeds (Sinapis alba L.). Lucr. Ştiinţifice Ser. Zooteh. 2014, 61, 39-44.

24. Paunović, D.; Šolević Knudsen, T.; Krivokapić, M.; Zlatković, B.; Antić, M. Sinalbin degradation products in mild yellow mustard paste. Hem. Ind. 2012, 66, 29-32. [CrossRef]

25. Young-Mathews, A. Plant guide for field mustard (Brassica rapa ssp. rapa). USDA-Natural Resources Conservation Service, Plant Materials Center, Corvallis. Available online: https://plants.usda.gov/plantguide/ pdf/pg_brrar.pdf (accessed on 20 September 2019).

26. Ryant, P. Effect of sulphur fertilisation on yield and quality of white mustard seeds. Acta Univ. Agric. Silvic. Mendel. Brun. 2009, 57, 95-104. [CrossRef]

27. Bloem, E.; Haneklaus, S.; Daniels, R.; Schnug, E. Influence of sulfur fertilization on floral scent patterns of crops in full bloom. Landbauforsch Volk. Appl. Agric. For. Res. 2010, 60, 45-50.

28. Filipek-Mazur, B.; Gondek, K. Yielding and sulphur content in white mustard as the effect of application of multi-component fertilizers containing sulphur. Acta Agrophys. 2005, 6, 343-351.

29. Barczak, B.; Kozera, W.; Knapowski, T.; Ralcewicz, M. Selected field components in white mustard (Sinapis alba) versus sulfur fertilization. J. Cent. Eur. Agric. 2011, 12, 380-389. [CrossRef]

30. Shekhawat, K.; Kandpal, B.K.; Chand, G.; Singh, D. Sulphur management for increased productivity of Indian mustard: A review. Ann. Plant. Soil Res. 2015, 17, 1-12.

31. Ray, K.; Sengupta, K.; Pal, A.K.; Banerjee, H. Effects of sulphur fertilization on yield, S uptake and quality of Indian mustard under varied irrigation regimes. Plant Soil Environ. 2015, 61, 6-10. [CrossRef]

32. Hawkesford, M.J. Plant responses to sulphur deficiency and the genetic manipulation of sulphate transporters to improve S-utilization efficiency. J. Exp. Bot. 2000, 51, 131-138. [CrossRef]

33. Mašauskiene, A.; Mašauskas, V. Soil sulphur problems and management. In Sustainable Agriculture. Series Ecosystem Health and Sustainable Agriculture; Jakobsson, C., Ed.; Baltic University Press: Uppsala, Sweden, 2012; pp. 113-116.

34. Eriksen, J. Sulphur Cycling in Agrosystems. Ph.D. Thesis, Aarhus University, Tjele, Denmark, 2010.

35. Procházková, D.; Pavlíková, D.; Pavlík, M. Sulphur: Role in alleviation of environmental stress in crop plants. In Plant-Environment Interaction: Responses and Approaches to Mitigate Stress; Azooz, M.M., Ahmad, P., Eds.; John Wiley \& Sons: Hoboken, NJ, USA, 2016; pp. 84-96. [CrossRef] 
36. Prasad, M.N.V. Heavy Metal. Stress in Plants: From Biomolecules to Ecosystems, 2nd ed.; Springer: Berlin/Heidelberg, Germany, 2004; p. 462. [CrossRef]

37. Maheshwari, R.; Dubey, R.S. Nickel-induced oxidative stress and the role of antioxidant defense in rice seedlings. Plant Growth Regul. 2009, 59, 37-49. [CrossRef]

38. Yadav, N.; Sharma, S. An account of nickel requirement, toxicity and oxidative stress in plants. Biol. Forum Int. J. 2016, 8, 414-419.

39. Barker, A.V.; Pilbeam, D.J. Handbook of Plant Nutrition, 2nd ed.; CRC Press: Boca Raton, FL, USA, $2015 ;$ p. 773.

40. Rahman, H.; Sabreen, S.; Alam, S.; Kawai, S. Effects of nickel on growth and composition of metal micronutrients in barley plants grown in nutrient solution. J. Plant Nutr. 2005, 28, 393-404. [CrossRef]

41. Yadav, S. Toxicity of Nickel in Plants and Its Interaction with Certain Micronutrient. Ph.D. Thesis, University of Lucknow, Lucknow, India, 2013.

42. Fageira, N.K. Mineral. Nutrition of Rice, 1st ed.; CRC Press: Boca Raton, FL, USA, 2013; p. 586. [CrossRef]

43. Aibara, I.; Miwa, K. Strategies for optimization of mineral nutrient transport in plants: Multilevel regulation of nutrient-dependent dynamics of root architecture and transporter activity. Plant Cell Physiol. 2014, 55, 2027-2036. [CrossRef]

44. Mitra, G.N. Regulation of Nutrient Uptake by Plants, 1st ed.; Springer: New Delhi, India, 2015; p. 195. [CrossRef]

45. Moosavi, A.A.; Mansouri, S.; Zahedifar, M. Effect of soil water stress and nickel application on micronutrient status of canola grown on two calcareous soils. Plant. Prod. Sci. 2015, 18, 377-387. [CrossRef]

46. Ernst, W.H.O.; Krauss, G.J.; Verkleij, J.A.C.; Wesenberg, D. Interaction of heavy metals with the sulphur metabolism in angiosperms from an ecological point of view. Plant Cell Environ. 2008, 31, 123-143. [CrossRef]

47. Ranade-Malvi, U. Interaction of micronutrients with major nutrients with special reference to potassium. Karnataka J. Agric. Sci. 2011, 24, 106-109.

48. Jankowski, K.J.; Budzyński, W.S.; Kijewski, Ł.; Klasa, A. Concentrations of cooper, zinc and manganese in the roots, straw and oil cake of white mustard (Sinapis alba L.) and Indian mustard (Brassica juncea (L.) Czern. et Coss) depending on sulphur fertilization. Plant Soil Environ. 2014, 60, 364-371. [CrossRef]

49. Matraszek, R.; Hawrylak-Nowak, B.; Chwil, M.; Chwil, S.; Rudaś, M. Effect of the interaction of nickel stress and sulphur supplementation on the content and accumulation of macronutrients in white mustard (Sinapis alba L.). Electron. J. Pol. Agric. Univ. 2017, 20, 1. [CrossRef]

50. Szatanik-Kloc, A.; Szerement, J.; Józefaciuk, G. The role of cell walls and pectins in cation exchange and surface area of plant roots. J. Plant Physiol. 2017, 215, 85-90. [CrossRef]

51. Freeman, J.L.; Persans, M.W.; Nieman, K.; Albrecht, C.; Peer, W.; Pickering, I.J.; Salt, D.E. Increased glutathione biosynthesis plays a role in nickel tolerance in Thlaspi nickel hyperaccumulators. Plant Cell 2004, 16, 2176-2191. [CrossRef] [PubMed]

52. Hossain, M.A.; Piyatida, P.; Texteira da Silva, J.A.; Fujita, M. Molecular mechanism of heavy metal toxicity and tolerance in plants: Central role of glutathione in detoxification of Reactive Oxygen Species and methylglyoxal and in heavy metal chelation. J. Bot. 2012, 2012, 872875. [CrossRef]

53. Viehweger, K. How plants cope with heavy metals? Bot. Stud. 2014, 55, 35. [CrossRef] [PubMed]

54. Hasanuzzaman, M.; Alam, M.M.; Nahar, K.; Mohsin, S.M.; Bhuyan, M.H.M.B.; Parvin, K.; Hawrylak-Nowak, B.; Fujita, M. Silicon-induced antioxidant defense and methylglyoxal detoxification works coordinately in alleviating nickel toxicity in Oryza sativa L. Ecotoxicology 2019, 28, 261. [CrossRef] [PubMed]

55. Jones, J.B., Jr. Laboratory Guide for Conducting Soil Tests and Plant Analysis, 1st ed.; CRC Press: Boca Raton, FL, USA, 2001; p. 363.

56. Aref, F. Concentration and uptake of zinc and boron in corn leaf as affected by zinc sulfate and boric acid fertilizers in a deficient soil. Life Sci. J. 2011, 8, 26-31.

57. Wolf, B. Improvements in the azomethine-H method for determination of boron. Commun. Soil Sci. Plant Anal. 1974, 5, 39-44. [CrossRef]

58. Nowosielski, O. Methods for the Determination of Fertilisation Requirements, 1st ed.; PWRiL: Warszawa, Poland, 1974. (In Polish)

(C) 2019 by the authors. Licensee MDPI, Basel, Switzerland. This article is an open access article distributed under the terms and conditions of the Creative Commons Attribution (CC BY) license (http://creativecommons.org/licenses/by/4.0/). 